Review article

\title{
Indications, risks and impact of failed allograft nephrectomy
}

\author{
Lisa Ghyselen $^{\mathrm{a}, \mathrm{b}}$, Maarten Naesens ${ }^{\mathrm{a}, \mathrm{b}, *}$ \\ a Department of Microbiology and Immunology, KU Leuven, University of Leuven, Leuven, Belgium \\ b Department of Nephrology and Renal Transplantation, University Hospitals Leuven, Leuven, Belgium
}

\section{A R T I C L E I N F O}

Available online $\mathrm{xxx}$

\section{Keywords:}

Allograft nephrectomy

Retransplantation

Kidney

Sensitization

Survival

\begin{abstract}
A B S T R A C T
In this review, we describe the indications, surgical aspects, benefits and risks of nephrectomy after graft failure. There is a great variation in the number of allograft nephrectomies performed among different centers. Nephrectomy of a failed allograft is associated with significant morbidity and mortality with a complication rate of 20$30 \%$ and mortality rates between $0 \%$ and $11 \%$. A systematic review through Medline (Pubmed) and Embase identified thirteen retrospective studies that compared patients with and patients without allograft nephrectomy prior to retransplantation. Allograft nephrectomy associates with an increased risk of HLA antibody development. With two recent studies that used the more sensitive HLA antibody detection methods disproving the hypothesis of intragraft adsorption of HLA antibodies, the mechanism leading to the increased HLA antibody levels is not clear, but the role of immunosuppression withdrawal is becoming clear and needs further investigation. In nine of the thirteen studies that evaluated the impact of allograft nephrectomy on outcome in retransplantation, retransplant graft survival was not significantly different among patients with and patients without allograft nephrectomy. Only three studies showed significantly worse retransplant graft survival if prior allograft nephrectomy was performed. Most studies did not observe a significant difference in patient survival after retransplantation with versus without prior allograft nephrectomy. All studies were affected by the retrospective design, indication bias, and selection bias. On the basis of the available literature on this topic, we did not identify a clear advantage or disadvantage of allograft nephrectomy, in terms of outcome after repeat transplantation. Nevertheless, the significantly increased risk of HLA antibody sensitization, especially in patients at high immunological risk like high donor-recipientHLA epitope mismatch load and HLA-DQB1 mismatches, argues against routine allograft nephrectomy and immunosuppression withdrawal in asymptomatic patients who are eligible for repeat transplantation.
\end{abstract}

(c) 2018 Elsevier Inc. All rights reserved.

\section{Introduction}

Twenty years ago, our research group studied the management of the failed renal allograft, with special reference to allograft nephrectomy and its effect on retransplant outcome [1]. Since then, a lot has changed in terms of donor selection, immunosuppression, rejection phenotypes, HLA laboratory techniques, etc. The results of renal transplantation are slowly improving, but still, about $15 \%$ of people transplanted in Europe experience graft failure during the first five years after transplantation [2]. In the United States the reported graft failure during the first five years after transplantation is $>20 \%$ [3]. Nowadays, renal retransplantation is an accepted alternative for return to dialysis after graft failure [4]. Graft survival after retransplantation is

Abbreviations: AN, allograft nephrectomy; DSA, donor-specific antibodies; ECAN, extracapsular allograft nephrectomy; GF, graft failure; GS, graft survival; HLA, human leukocyte antigen; ICAN, intracapsular allograft nephrectomy; NS, no significant difference; PRA, panel reactive antibodies; PS, patient survival.

* Corresponding author at: Department of Nephrology and Renal Transplantation, University Hospitals Leuven, Herestraat 49, 3000 Leuven, Belgium.

E-mail address: maarten.naesens@uzleuven.be (M. Naesens). inferior to primary graft survival, but remains fairly high [5-7]. Of alltransplantations performed in the United States, $13 \%$ are repeat transplantations [3].

Antibodies play a major role in transplantation, especially in case of retransplantation. The presence of a donor kidney leads to activation of the recipient's immune system and the potential formation of antihuman leukocyte antigen (HLA) antibodies. Such donor specific antibodies (DSA) can lead to antibody-mediated rejection and graft failure. Nephrectomy of a failed allograft is a potential HLA sensitizing event $[8,9]$.

Whether an asymptomatic failed renal allograft should be removed before retransplantation is still controversial, and medical practice varies from centre to centre. A failed renal allograft that remains in situ may induce a chronic inflammatory response syndrome (erythropoietin resistance, elevated C-reactive protein, hypoalbuminemia and malnutrition) that requires the use of immunosuppressive agents. On the other hand, allograft nephrectomy is associated with a certain morbidity and mortality $[10,11]$ and leads to loss of residual function (e.g. erythropoietin production, residual diuresis, etc.). Moreover, the higher levels of HLA antibody sensitization after allograft nephrectomy could 
Table 1

Advantages and disadvantages of a failed allograft nephrectomy.

\begin{tabular}{lc}
\hline Advantages & Disadvantages \\
\hline - Prevention of graft intol- & - Loss of residual function (e.g. erythropoietin \\
erance syndrome & production, residual diuresis, etc.) \\
- Resolution of graft related & - Surgical morbidity and mortality \\
symptoms or risks & - HLA antibody sensitization \\
- Possibility of immuno- & \\
- suppression withdrawal & \\
- Room for a new graft & \\
\hline
\end{tabular}

have a negative impact on retransplant outcome. Several advantages and disadvantages of allograft nephrectomy have been suggested in the literature (Table 1).

No randomized controlled trials have been performed to evaluate the benefit or risk of allograft nephrectomy prior to repeat kidney transplantation, and no clinical practice guidelines are available. Recently, two reviews discussing the management of a failed renal allograft were published. They mainly focus on the role of dialysis and the management of immunosuppression [12,13]. In the current review, we describe the clinical practices and surgical aspects of allograft nephrectomy, and provide an overview of the literature on the effect of allograft nephrectomy on retransplant outcome, with special reference to the role of HLA antibody sensitization.

\section{Method}

We performed a literature search through Medline (Pubmed) and Embase using the terms 'allograft nephrectomy', 'outcome', 'kidney retransplantation', 'renal transplantectomy' and 'antibodies'. The search for the term 'allograft nephrectomy' was limited to articles from 17th ofMay 2007 till 13th of May 2017. The other searches covered all articles till 13th of May 2017. Combinations of these terms were also used. References of the articles retrieved were also screened. In total, we identified 397 individual manuscripts. First, 311 articles were excluded based on title or abstract. The remaining 86 full text articles were read. There were no language limitations. Because of the limited literature available on the topic, there were no exclusion criteria according to study method. 72 of the articles were excluded because they did not evaluate the association between allograft nephrectomy and graft or patient survival after repeat transplantation. Of one eligible report, the full text was not retrievable and this manuscript was excluded from our report [14]. In total, 13 studies were included for qualitative synthesis (Table 2) [15-27].

\section{Results}

\subsection{Routine clinical practice and indications for allograft nephrectomy}

The number of allograft nephrectomies performed varies widely among centres. In the 13 studies included in this review, the rates of allograft nephrectomies in patients undergoing retransplantation varied from $20 \%$ to $80 \%$. When all subjects are counted together, the rate of allograft nephrectomy was 43\% (number of nephrectomies/number of repeat transplantations: 2241/5202; Table 2).

Only few, often small and retrospective studies reported the indications for allograft nephrectomy. In most cases, allograft nephrectomy was performed because of clinical symptoms or immediate risk. Indications for allograft nephrectomy can be divided into three categories: related to the kidney, related to the immunosuppression and those

Table 2

Characteristics of the studies that evaluated the association between allograft nephrectomy and outcome after repeat transplantation.

\begin{tabular}{|c|c|c|c|c|c|c|c|c|}
\hline First author & $\begin{array}{l}\text { Publication } \\
\text { year }\end{array}$ & Country & Study design & Sample size & $\begin{array}{l}\text { GS } \\
\text { analysed }\end{array}$ & $\begin{array}{l}\text { PS } \\
\text { analysed }\end{array}$ & $\begin{array}{l}\text { PRA } \\
\text { analysed }\end{array}$ & Conclusion \\
\hline $\begin{array}{l}\text { Sánchez-González et al. } \\
\text { [15] }\end{array}$ & 2016 & Spain & $\begin{array}{l}\text { Retrospective } \\
\text { Cohort study }\end{array}$ & $\begin{array}{l}\text { AN: } 21 \\
\text { No AN: } 42\end{array}$ & + & + & + & $\begin{array}{l}\text { - No significant differences in GS and PS } \\
\text { - AN: higher PRA levels }\end{array}$ \\
\hline Dinis et al. [16] & 2014 & Portugal & $\begin{array}{l}\text { Retrospective } \\
\text { Cohort study }\end{array}$ & $\begin{array}{l}\text { AN: } 76 \\
\text { No AN: } 50\end{array}$ & + & + & + & $\begin{array}{l}\text { - No significant differences in GS and PS } \\
\text { - AN: higher PRA levels }\end{array}$ \\
\hline Fadli et al. [17] & 2014 & France & $\begin{array}{l}\text { Retrospective } \\
\text { Cohort study }\end{array}$ & $\begin{array}{l}\text { AN: } 52 \\
\text { No AN: } 94\end{array}$ & + & + & + & $\begin{array}{l}\text { - No significant differences in GS and PS } \\
\text { - AN: higher PRA levels }\end{array}$ \\
\hline $\begin{array}{l}\text { Tittelbach-Helmrich } \\
\text { et al. [18] }\end{array}$ & 2014 & Germany & $\begin{array}{l}\text { Retrospective } \\
\text { Cohort study }\end{array}$ & $\begin{array}{l}\text { AN: } 245 \\
\text { No AN: } 60\end{array}$ & + & + & + & $\begin{array}{l}\text { - No significant differences in GS } \\
\text { - AN: better PS } \\
\text { - AN: higher median maximum PRA } \\
\text { levels }^{\mathrm{a}}\end{array}$ \\
\hline Lucarelli et al. [19] & 2013 & Italy & $\begin{array}{l}\text { Retrospective } \\
\text { Cohort study }\end{array}$ & $\begin{array}{l}\text { AN: } 28 \\
\text { No AN: } 112\end{array}$ & + & + & + & $\begin{array}{l}\text { - No significant differences in GS and PS } \\
\text { - No significant difference in PRA levels }\end{array}$ \\
\hline Surga et al. [20] & 2013 & France & $\begin{array}{l}\text { Retrospective } \\
\text { Cohort study }\end{array}$ & $\begin{array}{l}\text { AN: } 43 \\
\text { No AN: } 48\end{array}$ & + & - & + & $\begin{array}{l}\text { - No significant differences in GS } \\
\text { - No significant difference in PRA levels }\end{array}$ \\
\hline Schleicher et al. [21] & 2010 & Germany & $\begin{array}{l}\text { Retrospective } \\
\text { Cohort study }\end{array}$ & $\begin{array}{l}\text { AN: } 121 \\
\text { No AN: } 45\end{array}$ & + & + & + & $\begin{array}{l}\text { - AN: worse long-term GS } \\
\text { - No significant difference in PS } \\
\text { - AN: higher PRA levels }\end{array}$ \\
\hline Ahmad et al. [22] & 2009 & UK & $\begin{array}{l}\text { Retrospective } \\
\text { Cohort study }\end{array}$ & $\begin{array}{l}\text { AN: } 68 \\
\text { No AN: } 21\end{array}$ & + & + & + & $\begin{array}{l}\text { - No significant differences in GS and PS } \\
\text { - No significant difference in PRA levels }\end{array}$ \\
\hline Johnston et al. [23] & 2007 & US & $\begin{array}{l}\text { Retrospective } \\
\text { Cohort study }\end{array}$ & $\begin{array}{l}\text { AN: } 1290 \\
\text { No AN: } \\
2206\end{array}$ & + & - & + & $\begin{array}{l}\text { - AN: } \\
\text { - After early GF: better retransplant GS } \\
\text { - After late GF: worse retransplant GS } \\
\text { - AN: higher PRA levels }\end{array}$ \\
\hline Lair et al. [24] & 2005 & France & $\begin{array}{l}\text { Retrospective } \\
\text { Cohort study }\end{array}$ & $\begin{array}{l}\text { AN: } 83 \\
\text { No AN: } 157\end{array}$ & + & - & + & $\begin{array}{l}\text { - No significant difference in GS } \\
\text { - AN: higher PRA levels }\end{array}$ \\
\hline Yagmurdur et al. [25] & 2005 & Turkey & $\begin{array}{l}\text { Retrospective } \\
\text { Cohort study }\end{array}$ & $\begin{array}{l}\text { AN: } 21 \\
\text { No AN: } 32\end{array}$ & + & - & - & - Conflicting P-values reported \\
\hline Abouljoud et al. [26,28] & 1995 & US & $\begin{array}{l}\text { Retrospective } \\
\text { Cohort study }\end{array}$ & $\begin{array}{l}\text { AN: } 150 \\
\text { No AN: } 42\end{array}$ & + & - & + & $\begin{array}{l}\text { - AN: worse GS } \\
\text { - AN: higher PRA levels }\end{array}$ \\
\hline Sumrani et al. [27] & 1992 & US & $\begin{array}{l}\text { Retrospective } \\
\text { Cohort study }\end{array}$ & $\begin{array}{l}\text { AN: } 43 \\
\text { No AN: } 52\end{array}$ & + & - & + & $\begin{array}{l}\text { - No significant difference in GS } \\
\text { - AN: higher PRA levels }{ }^{\mathrm{b}}\end{array}$ \\
\hline
\end{tabular}

AN, allograft nephrectomy; GF, graft failure; GS, graft survival; PS, patient survival; PRA, panel reactive antibodies.

+ : this topic is examined in the study; -: this topic is not examined in the study.

a Mean maximum PRA levels and last recorded PRA levels before retransplantation not significantly different.

b Significantly higher PRA levels after AN because of symptoms, not after an elective AN. 
Table 3

Indications for allograft nephrectomy.

\begin{tabular}{|c|c|c|}
\hline Related to kidney & Related to immunosuppression & Unclear $^{\mathrm{a}}$ \\
\hline $\begin{array}{l}\text { - Technical failures } \\
\text { - Acute arterial or venous thrombosis } \\
\text { - Graft intolerance syndrome (graft pain and tenderness, fever, anaemia, persis- } \\
\text { tent haematuria, chronic inflammation) } \\
\text { - Uncontrolled hypertension } \\
\text { - Graft infection } \\
\text { - Haemorrhage } \\
\text { - Malignant tumour in the transplant kidney } \\
\text { - Need to create room for the new graft }\end{array}$ & $\begin{array}{l}\text { - Recurrent urinary tract infections } \\
\text { - Severe or recurrent sepsis } \\
\text { - Opportunistic infections } \\
\text { - Malignant tumour outside of the } \\
\text { kidney } \\
\text { - Other adverse effects of immuno- } \\
\text { suppressive drugs }\end{array}$ & $\begin{array}{l}\text { - Antibody formation (kidney as a trigger ver- } \\
\text { sus kidney as a sponge) } \\
\text { - Refractory acute rejection } \\
\text { - Recurrent primary disease } \\
\text { - Polyoma virus nephropathy } \\
\text { - Asymptomatic graft failure }\end{array}$ \\
\hline
\end{tabular}

a Cases in which allograft nephrectomy can be considered, but with insufficient literature concerning the pro's and contra's.

indications that are still controversial. We analysed the indications for allograft nephrectomy mentioned in the 13 studies we included and categorized them (Table 3). It is obvious that in case of an indication related to the kidney or to immunosuppression, with important impact on patients' general health, allograft nephrectomy should be performed. The third category represents indications of which it is less clear whether an allograft nephrectomy is recommended or not.

Given that there is no question about the need for transplant nephrectomy in urgent life-threatening situations (e.g. graft haemorrhage, graft thrombosis, graft infection, etc.), we were particularly interested in the impact of allograft nephrectomies performed in patients with asymptomatic graft failure.

As most of the allograft nephrectomies performed in the included studies were performed because of a clear clinical indication, it is difficult to draw conclusions with respect to elective surgery, in patients with asymptomatic graft failure. For future research and a better understanding of the role of elective transplant nephrectomy, more systematic data collection of the numbers, the indications and timing of allograft nephrectomies is warranted.

\subsection{Surgical procedure of allograft nephrectomy}

\subsubsection{Operative technique}

Two operative techniques exist for the performance of an allograft nephrectomy: an extracapsular and an intra- or subcapsular technique. The preferred technique depends on how long the kidney has been in place. In case of early allograft nephrectomy, only few adhesions are formed and the renal pedicle structures can be easily identified. An extracapsular allograft nephrectomy, with removal of the transplant in toto, is then recommended. If the allograft is in situ for a longer period of time, an intra- or subcapsular allograft nephrectomy is recommended. The kidney is freed within its capsule and the pedicle is split in order to remove the kidney. For both techniques, the approach is usually through the original transplant incision [28].

\subsubsection{Complications}

Several small studies reported on the complication rate of allograft nephrectomy, which vary between $5 \%$ and $48 \%$ [10,11,29-37]. Small sample sizes partly explain this variation between centres. In the most recent studies, the complication rate is about 20-30\% [29-31,37]. Mortality rates ranged from $0 \%$ to $11 \%$ [10,11,29-37], with postoperative infection as most common cause of death. Other reported causes of death after allograft nephrectomy, are intravascular coagulation, intestinal ischemia and bleeding [11,29-31,33,35,37].

Most common complications after allograft nephrectomy were postoperative bleeding and hematoma. Other common complications were infection (including sepsis), lymphocele, abscess formation and deep vein thrombosis $[10,11,29,30,32-37]$. Four studies investigated whether there is a difference in the number of complications between early and late allograft nephrectomies (Table 4). Two of them showed significantly more complications in the group of patients with early allograft nephrectomy: $59 \%$ versus $22 \%$ and $59 \%$ versus $12 \%$ [31,32]. A potential explanation for this difference is the fact that early allograft nephrectomies are more often urgent (with indications such as acute surgical problems, haemorrhage, thrombosis, etc.) and urgent allograft nephrectomies are associated with higher complication rates [35], although other studies did not confirm this [11,29]. Although not statistically significant, two studies found a trend to greater incidence of major complications in the group of patients with late allograft nephrectomy [11,31]. The reason for these discrepancies between studies is to be found in the heterogeneity in centre-dependent indications for allograft nephrectomy, small study sizes and the retrospective nature of these studies.

A possible difference in complication rate according to operation technique was investigated by four studies (Table 4). Most studies showed no difference in complication rate between the intracapsular and extracapsular technique $[10,11,31,33]$, but one study reported a non-significant trend towards higher rates of major complications with the intracapsular procedure [31].

Table 4

Surgical complications and mean blood loss: impact of timing and operation technique.

\begin{tabular}{|c|c|c|c|c|}
\hline \multirow[t]{2}{*}{ First author (publication year) } & \multicolumn{2}{|l|}{ Surgical complications } & \multicolumn{2}{|l|}{ Mean blood loss } \\
\hline & Early versus late nephrectomy & $\begin{array}{l}\text { Intracapsular versus } \\
\text { extracapsular nephrectomy }\end{array}$ & $\begin{array}{l}\text { Early versus late } \\
\text { nephrectomy }\end{array}$ & $\begin{array}{l}\text { Intracapsular versus } \\
\text { extracapsular nephrectomy }\end{array}$ \\
\hline Toth et al. $(2016)^{a}[29]$ & NS & - & - & - \\
\hline Freitas et al. (2015) [31] & Early $>$ late $^{\mathrm{b}}$ & $\mathrm{NS}^{\mathrm{c}}$ & Early > late & NS \\
\hline Sun et al. $(2013)^{d}[32]$ & Early $>$ late & - & - & - \\
\hline Vavallo et al. (2012) [10] & - & NS & - & NS \\
\hline Touma et al. (2011) [33] & - & NS & - & ICAN $<$ ECAN \\
\hline Mazzucchi et al. (2003) [11] & $\mathrm{NS}^{\mathrm{b}}$ & NS & Early $<$ late & ICAN $>$ ECAN \\
\hline
\end{tabular}

AN, allograft nephrectomy; ICAN, intracapsular allograft nephrectomy; ECAN, extracapsular allograft nephrectomy; NS, no significant difference.

-: not examined in this study.

a All AN's were ICAN's.

b Late AN: more major complications (NS).

c ICAN: more major complications (NS).

d All early AN's were extracapsular, all late AN's were intracapsular. 
Blood loss during surgery was investigated in four studies (Table 3 ). Minimizing blood loss and especially blood transfusions could also be important in the light of a possible retransplantation. Blood transfusions could be associated with the formation of antibodies, which makes it more difficult to find an acceptable kidney graft in the future [38]. Two studies associated the mean blood loss during surgery with allograft nephrectomy timing: while one study showed significantly more blood loss during early allograft nephrectomies [31], the other study showed significantly more blood loss during late allograft nephrectomies [11]. When comparing the mean blood loss between intra- and extracapsular allograft nephrectomy, conflicting results were found as well. One study showed significantly more blood loss during the extracapsular procedure [33], whereas another one showed significantly more blood loss in case of an intracapsular approach [11]. In two other studies, no significant difference was found between both surgical techniques $[10,31]$.

In summary, given the large variation in outcome between different studies, no strong conclusions can be reached regarding the best timing and the most suitable surgical approach for allograft nephrectomy. Centre experience and urgency of the indication are currently the only decisive factors.

\subsection{Allograft nephrectomy and HLA antibody sensitization}

Allograft nephrectomy is associated with HLA antibody sensitization, which is problematic for patients who need a second transplant. A recent study found significantly higher DSA levels at last follow-up in patients with allograft nephrectomy compared to those without: $81 \%$ and $52 \%$, respectively [8], confirming previous studies [9,39-41]. Twelve of the 13 studies included for qualitative synthesis investigated the impact of allograft nephrectomy on PRA levels (Table 2). PRA levels ranged from $20 \%$ to $72 \%$ in patients with allograft nephrectomy and from $10 \%$ to $55 \%$ in patients without allograft nephrectomy $[15,16,19$ 23]. In seven studies, PRA levels were significantly higher in patients with allograft nephrectomy compared to patients without allograft nephrectomy [15-17,21,23,24,26]. Four other studies did not observe a statistically significant association between PRA levels and allograft nephrectomy $[18-20,22]$. One study made a distinction between patients without allograft nephrectomy, patients who underwent allograft nephrectomy because of symptoms and patients with an elective allograft nephrectomy. Patients who underwent allograft nephrectomy because of symptoms had significantly higher PRA levels than those with an elective allograft nephrectomy or without allograft nephrectomy: 57\%, $33 \%$ and $25 \%$, respectively [27], but this was not confirmed in a more recent study [8]. As more donor tissue remains in situ after the intracapsular procedure, it could be hypothesized that this leads higher PRA levels after intracapsular allograft nephrectomy. Nevertheless, one study comparing both operation techniques found no significant difference in PRA levels [31].

Currently, two opposing theories concerning antibody formation exist. According to the first theory, keeping a failed renal allograft in place is a trigger for antibody formation, due to continued exposure of the recipient's immune system to non-self antigens of donor origin. In contrast, according to the sponge theory, anti-HLA antibodies that are formed as a consequence of sensitization are absorbed by the graft and therefore not easily detectable in serum. After allograft nephrectomy, this absorption is lacking, which may increase the serum levels of the antibodies. Both theories demand for a completely opposite strategy, as in the first case allograft nephrectomy seems recommended to avoid antibody formation, while in the second case the renal allograft could be retained in situ. Finally, the surgical procedure of nephrectomy and manipulation of the kidney in itself and related inflammation may induce some non-specific stimulation of the immune system, as is the case for most major surgery [42], culminating in increased risk of antibody formation.
To test the "sponge/sink theory", four studies compared the presence of anti-HLA antibodies in the sera of patients and in eluates from the failed grafts. The "sponge theory" was supported by two older studies that found higher rates of patients with antibodies present in the eluates than in the sera $[43,44]$. However, two more recent studies, performed with sensitive detection techniques, showed that all antiHLA antibodies detected in the eluates were also detected in the sera, clearly refuting the "sponge hypothesis" as cause of antibody sensitization $[45,46]$. It is therefore no longer possible to propose the "sponge theory" as single cause of antibody occurrence after allograft nephrectomy. Nevertheless, the sponge effect could still play a role in the level of circulating HLA antibodies. The same research group of one of the latter studies earlier found a significant rise of HLA antibodies as soon as 5 days after an allograft nephrectomy [8]. This pleads for the existence of preformed antibodies as well.

Withdrawal of immunosuppression at time of or after graft failure represents another confounder that likely plays a major role in HLA antibody sensitization. This was illustrated in two studies that showed an association between withdrawal of immunosuppression and HLA antibody sensitization: $66-68 \%$ of patients who discontinued immunosuppression became sensitized, compared to only $0-8 \%$ of patients continuing immunosuppression $[47,48]$. Another study described sensitization rates at retransplant evaluation to be significantly different between patients with early immunosuppression withdrawal $(<3 \mathrm{~m}$ after failure; 70\% sensitization) and late immunosuppression withdrawal (>3 months after graft failure; 33\% sensitization), also adjusted for cofactors such as blood transfusion and allograft nephrectomy [49]. The role of immunosuppression withdrawal was confirmed in a recent study where immunosuppression withdrawal was an independent risk factor for HLA antibody sensitization after graft failure [50]. Interestingly, this risk of sensitisation after graft failure and immunosuppression withdrawal depends on the donor-recipientHLA-DQB1 eplet mismatches [50]. Recently, we also described the importance of HLADQB1 epitope mismatches and total epitope mismatch load in HLA antibody sensitization after graft failure in patients eligible for repeat transplantation [51], which confirms the potential of stratifying patients based on advanced HLA mismatch analysis. For more extensive information on the side effects of immunosuppressive agents (infections, cardiovascular risk, metabolic complications, malignancies), and the pros and cons to stop immunosuppressants after graft failure, we refer to the recent review by Bunthof et al. [13].

These studies used different assays with different sensitivities to detect anti-HLA antibodies, complicating the comparison between the studies. Another limitation of the studies included for qualitative synthesis is the fact that in most studies PRA levels were not measured routinely, and there is important selection bias. One should also keep in mind that most of the allograft nephrectomies were performed because of symptoms, with acute and less defined chronic rejection as important causes. Allograft nephrectomy is thus possibly a sign of (highly) immunized patients in these series, rather than the cause of immunization. Performing these analyses with the currently used high-sensitivity tools for HLA antibody detection and identification, and in systematic unbiased follow-up, is necessary to elucidate this association between allograft nephrectomy and the increased risk of HLA antibody sensitization in more detail.

\subsection{The impact of allograft nephrectomy on retransplant outcome}

Thirteen studies investigated the impact of allograft nephrectomy on retransplant outcome. The characteristics of these 13 studies are summarized in Table 2.

\subsubsection{Delayed graft function (DGF) and acute rejection}

As discussed above, allograft nephrectomy associates with HLA antibody sensitization, which is an important risk factor for post-transplant outcome, including the risk for acute (antibody-mediated) rejection and 
Table 5

Retransplant graft and patient survival with and without prior allograft nephrectomy.

\begin{tabular}{|c|c|c|c|c|c|c|}
\hline \multirow[t]{2}{*}{ First author (publication year) } & \multicolumn{3}{|l|}{ Graft survival } & \multicolumn{3}{|l|}{ Patient survival } \\
\hline & AN & No AN & P-value & Allograft nephrectomy & $\begin{array}{l}\text { No allograft } \\
\text { nephrectomy }\end{array}$ & P-value \\
\hline Dinis et al. (2014) [16] & $\begin{array}{l}\cdot 1-y: 96.6 \% \\
\cdot 3-y: 90.7 \% \\
\text { • } 5-y: 83.4 \%\end{array}$ & $\begin{array}{l}\cdot 1-y: 95.0 \% \\
\cdot 3-y: 82.0 \% \\
\text { - 5-y: } 68.4 \%\end{array}$ & NS & $5-y: 89.3 \%$ & $5-y: 82.8 \%$ & NS \\
\hline Fadli et al. (2014) [17] & $\begin{array}{l}\cdot 1-y: 94 \% \\
\cdot 5-y: 81 \% \\
\cdot 10-y: 58 \%\end{array}$ & $\begin{array}{l}\bullet 1-y: 99 \% \\
\cdot 5-y: 93 \% \\
\cdot 10-y: 66 \%\end{array}$ & NS & $3.8 \%$ deaths & 7.4\% deaths & NS \\
\hline Tittelbach-Helmrich et al. $(2014)^{\mathrm{a}}[18]$ & $\begin{array}{l}\cdot 1-y: 81.4 \% \\
\cdot 5-y: 62.4 \% \\
\cdot 10-y: 46.3 \%\end{array}$ & $\begin{array}{l}\cdot 1-y: 66.8 \% \\
\cdot 5-y: 59.0 \% \\
\cdot 10-y: 30.2 \%\end{array}$ & 0.01 & $\begin{array}{l}\cdot 1-y: 94.1 \% \\
\cdot 5-y: 86.3 \% \\
\cdot 10-y: 72.2 \%\end{array}$ & $\begin{array}{l}\cdot 1-y: 79.2 \% \\
\cdot 5-y: 73.1 \% \\
\cdot 10-y: 44.1 \%\end{array}$ & $<0.01$ \\
\hline Surga et al. (2013) [20] & $\begin{array}{l}\cdot 1-y: 95.0 \% \\
\cdot 5-y: 91.0 \% \\
\cdot 10-y: 84.9 \%\end{array}$ & $\begin{array}{l}\cdot 1-y: 95.6 \% \\
\cdot 5-y: 82.7 \% \\
\cdot 10-y: 68.9 \%\end{array}$ & NS & - & - & - \\
\hline Ahmad et al. (2009) [22] & $\begin{array}{l}\bullet 1-y: 83.8 \% \\
\bullet-3-y: 76.0 \% \\
\cdot 5-y: 66.2 \%\end{array}$ & $\begin{array}{l}\bullet 1-y: 94.7 \% \\
\text { • 3-y: } 86.8 \% \\
\text { • 5-y: } 69.5 \%\end{array}$ & NS & 5-y: $94.1 \%$ & $5-y: 87.5 \%$ & NS \\
\hline Lair et al. (2005) [24] & $\begin{array}{l}\cdot 1-\mathrm{y}: 92 \% \\
\cdot 5-\mathrm{y}: 81 \% \\
\cdot 10-\mathrm{y}: 62 \%\end{array}$ & $\begin{array}{l}\cdot 1-\mathrm{y}: 92 \% \\
\cdot 5-\mathrm{y}: 79 \% \\
\cdot 10-\mathrm{y}: 65 \%\end{array}$ & NS & - & - & - \\
\hline
\end{tabular}

AN, allograft nephrectomy; NS, no significant difference; GF, graft failure; reTx, retransplantation.

-: no mean survival or survival rates reported in this study.

We did not include the references to Sanchez [15], Lucarelli (REF) [19], Schleicher [21,23], because the exact survival metrics were not clear or comparable with the other references.

a No significant difference when the analysis was censored for death with a functioning graft.

DGF. Ten studies investigated the effect of allograft nephrectomy on the occurrence of DGF after retransplantation, and 4 described a significant association $[15,23,26,27]$. Six other studies however did not confirm such relation $[16,17,19-21,24]$. Eleven studies investigated the effect of allograft nephrectomy on the incidence of acute rejection after retransplantation, again with mixed results: while 8 studies did not observe an association [15,17,19,20,22,24,26,27], three studies found a significantly higher rate of acute rejections in patients who underwent allograft nephrectomy of the previous kidney graft [16,21,25]. A major drawback of all studies that investigated the relation between prior allograft nephrectomy, DGF and acute rejection after retransplantation is that it remains unclear if the results were corrected for the potential presence of HLA antibodies. This could explain the higher rates of DGF and acute rejection in patients with allograft nephrectomy. As mentioned above, all these analyses are heavily affected by indication bias: allograft nephrectomy is sometimes performed for graft inflammation, potentially caused by HLA antibodies, rather than being the cause of immunization. Higher rates of DGF and acute rejection after retransplantation could then be an indication of sensitization, which is not necessarily related to the allograft nephrectomy per se. Better-controlled prospective studies are necessary to evaluate the potential role of allograft nephrectomy in DGF of a repeat transplant.

\subsubsection{Graft failure}

Also with regards to the potential association between previous allograft nephrectomy and graft failure of a repeat transplantation, the literature remains totally inconclusive. All 13 studies investigated the impact of allograft nephrectomy on retransplant graft survival (Table 5). Reported one-year graft survival rates in patients with allograft nephrectomy and patients without allograft nephrectomy ranged from 81 to $97 \%$ and from 67 to $99 \%$, respectively. Five-year graft survival rates reported by the same studies ranged from $45 \%$ to $91 \%$ and from $59 \%$ to $93 \%$, respectively [ $16-18,20,22,24,25]$. One study found a significant association between allograft nephrectomy and graft failure after repeat transplantation, but only in patients with late failure $(>12$ months post-transplantation) of the primary transplant (HR 1.20, 95\% CI 1.02-1.41) [23]. In patients with early failure of the primary transplant, allograft nephrectomy was significantly associated with better retransplant graft survival (HR 0.72, 95\% CI 0.56-0.94), but results were no longer significant if death was censored as a cause of graft loss (HR 0.78, 95\% CI 0.57-1.06) [23]. The other studies did not report statistically significant relations between allograft nephrectomy and graft failure [15-22,25], irrespective of the timing or indication for the transplant nephrectomy $[26,27]$. All these analyses are importantly affected by selection bias, as only those patients who were fit for a repeat transplantation could be assessed, and as sensitized patients are usually transplanted with a matched donor organ, sometimes after significantly increased waiting times in dialysis associated with HLA antibody sensitization.

\subsubsection{Patient survival}

Seven studies investigated the impact of allograft nephrectomy on patient survival after retransplantation (Table 5). Six studies did not observe statistically significant associations [15-19,21,22]. No firm conclusions can be reached from these studies.

\section{Conclusion}

In conclusion, nephrectomy of a failed allograft is a surgical procedure associated with significant morbidity and mortality. Moreover, except from one, all studies found increased HLA antibody sensitization after allograft nephrectomy. Both a sponge/sink effect and sensitization due to the nephrectomy procedure could play a role, next to the effect of immunosuppression withdrawal. On the basis of the available literature on this topic, we did not identify a clear advantage or disadvantage of allograft nephrectomy, in terms of outcome after repeat transplantation. Nevertheless, the significantly increased risk of HLA antibody sensitization, especially in patients at high immunological risk like high donorrecipientHLA epitope mismatch load and HLA-DQB1 mismatches, argues against routine allograft nephrectomy and immunosuppression withdrawal in asymptomatic patients who are eligible for repeat transplantation.

This analysis has some important limitations. First, all studies included were retrospective and primarily from single centers. Most studies were limited by small sample sizes and in almost all cases, allograft nephrectomy was performed because of a clear clinical indication. This makes it difficult to extrapolate our findings to patients with an asymptomatic failed renal allograft. Finally, over the past two decades, antibody detection techniques and immunosuppressive protocols have 
changed, and careful interpretation of the results represented in those studies is thus recommended.

Prospective studies are warranted to overcome the important limitations of the literature available to date. Systematic measurement of HLA antibody levels and specificities at different time points after graft failure in all patients, including those that are not put on the wait list for a repeat transplant, would provide important information concerning sensitization and its potential impact on retransplant outcome. Randomization of patients into groups continuing and discontinuing immunosuppression would help to differentiate between the role of allograft nephrectomy and immunosuppression withdrawal in the risk of antibody sensitization. A systematic data collection of the number, the indications and the timing of allograft nephrectomies performed nationally and internationally would help future researchers investigating this topic and advance clinical practice.

\section{Declarations of interest}

none.

\section{Funding}

This work was supported by the Seventh Framework Programme (FP7) of the European Commission, in the HEALTH.2012.1.4-1 theme [grant number 305499]; The Research Foundation Flanders (F.W.O.) and Flanders Innovation and Entrepreneurship(Agentschap Innoveren en Ondernemen) of the Flemish Government [grant numbers IWT.2015.0199 and T004417N]; and KU Leuven [grant number C32/ $17 / 049]$.

\section{References}

[1] Vanrenterghem Y, Khamis S. The management of the failed renal allograft. Nephrol Dial Transplant 1996;11:955-7.

[2] Coemans M, Caner S, Döhler B, Anglicheau D, Giral M, Bestard O, et al. Short- and long-term graft survival after kidney transplantation in Europe between 1986 and 2015. Kidney Int 2018. https://doi.org/10.1016/j.kint.2018.05.018 prepub.

[3] Hart A, Smith JM, Skeans MA, Gustafson SK, Stewart DE, Cherikh WS, et al. OPTN/ SRTR 2015 annual data report: Kidney. Am J Transplant 2017;17:21-116.

[4] Ojo A, Wolfe RA, Agodoa LY, Held PJ, Port FK, Leavey SF, et al. Prognosis after primary renal transplant failure and the beneficial effects of repeat transplantation: multivariate analyses from the United States Renal Data System. Transplantation 1998;66: 1651-9.

[5] Ahmed K, Ahmad N, Khan MS, Koffman G, Calder F, Taylor J, et al. Influence of number of retransplants on renal graft outcome. Transplant Proc 2008;40:1349-52.

[6] Pour-Reza-Gholi F, Nafar M, Saeedinia A, Farrokhi F, Firouzan A, Simforoosh N, et al. Kidney retransplantation in comparison with first kidney transplantation. Transplant Proc 2005;37:2962-4.

[7] Coupel S, Giral-Classe M, Karam G, Morcet JF, Dantal J, Cantarovich D, et al. Ten-year survival of second kidney transplants: impact of immunologic factors and renal function at 12 months. Kidney Int 2003;64:674-80.

[8] Del Bello A, Congy-Jolivet N, Sallusto F, Guilbeau-Frugier C, Cardeau-Desangles I, Fort $\mathrm{M}$, et al. Donor-specific antibodies after ceasing immunosuppressive therapy, with or without an allograft nephrectomy. Clin J Am Soc Nephrol 2012;7:1310-9.

[9] Khakhar AK, Shahinian VB, House AA, Muirhead N, Hollomby DJ, Leckie SH, et al. The impact of allograft nephrectomy on percent panel reactive antibody and clinical outcome. Transplant Proc 2003;35:862-3.

[10] Vavallo A, Lucarelli G, Bettocchi C, Tedeschi M, Palazzo S, Losappio V, et al. Allograft nephrectomy: what is the best surgical technique? Transplant Proc 2012;44: 1922-5.

[11] Mazzucchi E, Nahas WC, Antonopoulos IM, Piovesan AC, Ianhez LE, Arap S. Surgical complications of graft nephrectomy in the modern transplant era. J Urol 2003;170: 734-7.

[12] Lea-Henry T, Chacko B. Management considerations in the failing renal allograft. Nephrol Ther 2018;23:12-9.

[13] Bunthof KLW, Hazzan M, Hilbrands LB. Review: Management of patients with kidney allograft failure. Transplant Rev (Orlando) 2018;32:178-86.

[14] Douzdjian V, Rice JC, Carson RW, Gugliuzza KK, Fish JC. Renal retransplants: effect of primary allograft nephrectomy on early function, acute rejection and outcome. Clin Transplant 1996;10:203-8.

[15] Sanchez-Gonzalez A, Carrasco-Valiente J, Arenas-Bonilla AJ, Campos-Hernandez JP, Blanca-Pedregosa A, Ruiz-Garcia JM, et al. Graft survival in patients who received second allograft, comparing those with or without previous failed allograft nephrectomy. Transplant Proc 2016;48:2895-8.
[16] Dinis P, Nunes P, Marconi L, Furriel F, Parada B, Moreira P, et al. Kidney retransplantation: removal or persistence of the previous failed allograft? Transplant Proc 2014;46:1730-4.

[17] Fadli SE, Pernin V, Nogue E, Macioce V, Picot MC, Ramounau-Pigot A, et al. Impact of graft nephrectomy on outcomes of second kidney transplantation. Int J Urol 2014; 21:797-802.

[18] Tittelbach-Helmrich D, Pisarski P, Offermann G, Geyer M, Thomusch O, Hopt UT et al. Impact of transplant nephrectomy on peak PRA levels and outcome after kidney re-transplantation. World J Transplant 2014;4:141-7.

[19] Lucarelli G, Vavallo A, Bettocchi C, Losappio V, Gesualdo L, Grandaliano G, et al. Impact of transplant nephrectomy on retransplantation: a single-center retrospective study. World J Urol 2013;31:959-63.

[20] Surga N, Viart L, Wetzstein M, Mazouz H, Collon S, Tillou X. Impact of renal graft nephrectomy on second kidney transplant survival. Int Urol Nephrol 2013;45: 87-92.

[21] Schleicher C, Wolters H, Kebschull L, Anthoni C, Suwelack B, Senninger N, et al. Impact of failed allograft nephrectomy on initial function and graft survival after kidney retransplantation. Transpl Int 2011;24:284-91.

[22] Ahmad N, Ahmed K, Mamode N. Does nephrectomy of failed allograft influence graft survival after re-transplantation? Nephrol Dial Transplant 2009;24 639-42.

[23] Johnston O, Rose C, Landsberg D, Gourlay WA, Gill JS. Nephrectomy after transplant failure: current practice and outcomes. Am J Transplant 2007;7:1961-7.

[24] Lair D, Coupel S, Giral M, Hourmant M, Karam G, Usal C, et al. The effect of a first kidney transplant on a subsequent transplant outcome: an experimental and clinical study. Kidney Int 2005;67:2368-75.

[25] Yagmurdur MC, Emiroglu R, Ayvaz I, Sozen H, Karakayali H, Haberal M. The effect of graft nephrectomy on long-term graft function and survival in kidney retransplantation. Transplant Proc 2005;37:2957-61.

[26] Abouljoud MS, Deierhoi MH, Hudson SL, Diethelm AG. Risk factors affecting second renal transplant outcome, with special reference to primary allograft nephrectomy. Transplantation 1995;60:138-44.

[27] Sumrani N, Delaney V, Hong JH, Daskalakis P, Sommer BG. The influence of nephrectomy of the primary allograft on retransplant graft outcome in the cyclosporine era. Transplantation 1992;53:52-5.

[28] Morris PJ, Knechtle S. Kidney transplantation: Principles and practice. 6th ed. Philadelphia: Saunders/Elsevier; 2008.

[29] Toth F, Zadori G, Fedor R, Illesy L, Szabo-Pap M, Kanyari Z, et al. A single-center experience of allograft nephrectomies following kidney transplantation. Transplant Proc 2016:48:2552-4.

[30] Bonilla AJ, Alfaro AG, Henandez JP, Rubio JH, Gomez EG, Valiente JC, et al. Review of a transplantectomy series. Transplant Proc 2015;47:81-3.

[31] Freitas R, Malheiro J, Santos C, Costa R, Martins LS, Almeida M, et al. Allograft nephrectomy: a single-institution, 10-year experience. Transplant Proc 2015;47: 992-5.

[32] Sun IO, Hong YA, Park HS, Choi SR, Chung BH, Kim JI, et al. Comparison of the clinical characteristics of renal transplant recipients who underwent early versus late graft nephrectomy. Transplant Proc 2013;45:2953-6.

[33] Touma NJ, Sener A, Caumartin Y, Warren J, Nguan CY, Luke PP. Extracapsular versus intracapsular allograft nephrectomy: impact on allosensitization and surgical outcomes. Can Urol Assoc J 2011;5:49-52.

[34] Emiroglu R, Sevmis S, Moray G, Karakayali H, Bilgin N, Yagmurdur MC, et al. One center's experience with allograft nephrectomy. Transplant Proc 2003 35:2668-9.

[35] Secin FP, Rovegno AR, del Rosario Brunet M, Marrugat RE, Davalos Michel M, Fernandez H. Cumulative incidence, indications, morbidity and mortality of transplant nephrectomy and the most appropriate time for graft removal: only nonfunctioning transplants that cause intractable complications should be excised. J Urol 2003;169:1242-6

[36] Zargar MA, Kamali K. Reasons for transplant nephrectomy: a retrospective study of 60 cases. Transplant Proc 2001;33:2655-6.

[37] Ariyarathenam A, Bamford A, Akoh JA. Transplant nephrectomy - a single-center experience. Saudi J Kidney Dis Transpl 2015;26:1108-12.

[38] Karpinski M, Pochinco D, Dembinski I, Laidlaw W, Zacharias J, Nickerson P. Leukocyte reduction of red blood cell transfusions does not decrease allosensitization rates in potential kidney transplant candidates. J Am Soc Nephrol 2004;15:818-24.

[39] Knight MG, Tiong HY, Li J, Pidwell D, Goldfarb D. Transplant nephrectomy after allograft failure is associated with allosensitization. Urology 2011;78:314-8.

[40] Billen EV, Christiaans MH, Lee J, van den Berg-Loonen EM. Donor-directedHLA antibodies before and after transplantectomy detected by the luminex single antigen assay. Transplantation 2009;87:563-9.

[41] Sener A, Khakhar AK, Nguan CY, House AA, Jevnikar AM, Luke PP. Early but not late allograft nephrectomy reduces allosensitization after transplant failure. Can Uro Assoc J 2011:5:E142-7.

[42] Watt DG, Horgan PG, McMillan DC. Routine clinical markers of the magnitude of the systemic inflammatory response after elective operation: a systematic review. Surgery 2015;157:362-80.

[43] Martin L, Guignier F, Mousson C, Rageot D, Justrabo E, Rifle G. Detection of donorspecificanti-HLA antibodies with flow cytometry in eluates and sera from renal transplant recipients with chronic allograft nephropathy. Transplantation 2003;76: 395-400.

[44] Bocrie O, Hussein Aly AA, Guignier F, Funes De La Vega M, Rifle G, Mousson C et al. Distribution of donor-specific antibodies in the cortex and the medulla of renal transplants with chronic allograft nephropathy. Transpl Immunol 2007; 17:227-9. 
[45] Milongo D, Kamar N, Del Bello A, Guilbeau-Frugier C, Sallusto F, Esposito L, et al. Allelic and epitopic characterization of intra-kidney allograft anti-HLA antibodies at allograft nephrectomy. Am J Transplant 2017;17:420-31.

[46] Bachelet T, Couzi L, Lepreux S, Legeret M, Pariscoat G, Guidicelli G, et al. Kidney intragraft donor-specific antibodies as determinant of antibody-mediated lesions and poor graft outcome. Am J Transplant 2013;13:2855-64.

[47] Augustine JJ, Woodside KJ, Padiyar A, Sanchez EQ Hricik DE, Schulak JA. Independent of nephrectomy, weaning immunosuppression leads to late sensitization after kidney transplant failure. Transplantation 2012;94:738-43.

[48] Scornik JC, Kriesche HU. Human leukocyte antigen sensitization after transplant loss: timing of antibody detection and implications for prevention. Hum Immunol 2011; 72:398-401.
[49] Casey MJ, Wen X, Kayler LK, Aiyer R, Scornik JC, Meier-Kriesche HU. Prolonged immunosuppression preserves nonsensitization status after kidney transplant failure. Transplantation 2014;98:306-11.

[50] Singh P, Filippone EJ, Colombe BW, Shah AP, Zhan T, Harach M, et al. Sensitization trends after renal allograft failure: the role of DQ eplet mismatches in becoming highly sensitized. Clin Transplant 2016;30:71-80.

[51] Daniels L, Naesens M, Bosmans JL, Abramowicz D, Nagler E, Van Laecke S, et al. The clinical significance of epitope mismatch load in kidney transplantation: a multicentre study. Transpl Immunol 2018. https://doi.org/10.1016/j.trim.2018.06. 006 prepub. 